\title{
OCCURRENCE AND ANTIBIOGRAM OF GENERIC EXTENDED- SPECTRUM CEPHALOSPORIN-RESISTANT AND EXTENDED-SPECTRUM 乃-LACTAMASE-PRODUCING ENTEROBACTERIA IN HORSES
}

\author{
Madubuike Umunna Anyanwu, Ifeoma Chinyere Ugwu, Collins Uchenna Onah \\ Department of Veterinary Pathology and Microbiology, University of Nigeria, \\ 400001 Nsukka, Enugu State Nigeria
}

Received 30 October 2017; Received in revised form 4 April 2018; Accepted 30 April 2018

\begin{abstract}
This study was conducted to isolate generic extended-spectrum cephalosporin (ESC)-resistant and extended-spectrum $\beta$-lactamase (ESBL)-producing enterobacteria from horses in Nigeria, and to determine the antibacterial resistance profile. Rectal swabs were collected from 155, systematic randomly selected, apparently-healthy horses. Isolation of ESC-resistant enterobacteria was done using Mac Conkey agar with ceftazidime. ESBL production was assessed by combination disc method. Resistance of the isolates was determined using disc diffusion method. Out of 155 samples, $5.2 \%$ gave positive growth. From these, 11 ESC-resistant enterobacteria comprising of $36.4 \%$ E. coli, $36.4 \%$ Salmonella spp. and $27.2 \%$ Proteus spp., were obtained. From 11 isolates, $45.5 \%$ consisting of all the 4 E. coli and 1 Proteus isolates, were ESBL-producers, these were recovered from $4(2.6 \%)$ out of the 155 horses sampled. Resistance of the E. coli isolates was $25 \%$ to aztreonam (AZT), 75\% to amoxicillin-clavulanic acid (AMC), gentamicin (GEN), perfloxacin (PEF), and sulphamethoxazoletrimethoprim (SXT-TRI), $50 \%$ to ofloxacin (OFL) and 100\% to ampicillin (AMP), ceftazidime (CTZ), cefotaxime (CTX), chloramphenicol (CHL), streptomycin (STR), tetracycline (TET), sparfloxacin (SPA), ciprofloxacin (CIP), norfloxacin (NOR) and enrofloxacin (ENR). Resistance of the Salmonella isolates was 50\% to PEF and 100\% to CTZ, CTX, AMP, AZT, AMC, CHL, GEN, STR, TET, SPA, CIP, OFL, NOR and ENR. Resistance of the Proteus isolates was $25 \%$ to AMC, CHL, STR, TET, SPA and NOR, and $100 \%$ to CTZ, CTX, AZT and AMP. Resistance of the isolates to more than 3 classes of antibacterial agents tested was $75 \%$ for Proteus and $100 \%$ for E. coli and Salmonella, respectively. This study showed that horses in Nigeria are potential reservoirs and disseminators of ESC-resistant and ESBL-producing Enterobacteriaceae.
\end{abstract}

Key words: antibiogram, extended-spectrum cephalosporin-resistant, extended-spectrum $\beta$-lactamase-producing, Enterobactericeae, equine

\section{INTRODUCTION}

There is increased interest in extended-spectrum cephalosporin (ESC)-resistant Enterobactericeae, because these organisms jeopardize $\operatorname{ESC}\left(3^{\text {rd }}\right.$ and $4^{\text {th }}$-generation cephalosporins which are critically-important in human and veterinary medicine) therapy and also exhibit resistance to other classes of antibacterials used in human and

Corresponding author: Dr. Madubuike Umunna Anyanwu, DVM, MSc E-mail address: madubuike.anyanwu@unn.edu.ng

Present address: Department of Veterinary Pathology and Microbiology, University of Nigeria, Nsukka, 400001 Nsukka, Enugu State Nigeria Phone: +2348132662827

Copyright: (C) 2018 Anyanwu M.U. This is an open-access article published under the terms of the Creative Commons Attribution License which permits unrestricted use, distribution, and reproduction in any medium, provided the original author and source are credited. Competing Interests: The authors have declared that no competing interests exist.

Available Online First: 31 May 2018

Published on: 15 October 2018

https://doi.org/10.2478/macvetrev-2018-0015 veterinary medicine, including chloramphenicol, fluoroquinolones, tetracycline, trimethoprim and sulphonamides (1, 2). Recently, ESC-resistant Enterobacteriaceae were classified as "critical priority 1 pathogens" that pose a threat to human and animal health and against which new treatment strategies are urgently needed (3), therefore there is a need to document their occurrence in different potential reservoirs. ESC resistance in Enterobacteriaceae is mediated by the production of $\beta$-lactamases, especially the extendedspectrum $\beta$-lactamases (ESBL) which hydrolyze all generations/subclasses of $\beta$-lactams except cephamycins and carbapenems, but are inhibited by $\beta$-lactamase-inhibitors (e.g., clavulanic acid), and Ampicillinase (Amp) $\mathrm{C} \beta$-lactamases which also hydrolyze $\beta$-lactamase-inhibitors (4).

Nigeria has an estimated horse population of 200,000-240,000 $(5,6)$; most of these horses are 
raised in the northern region of the country where they are used for pleasure riding, sports (especially polo games), ceremonies (such as dubar festival), entertainment, security purposes, crowd control (in police mountain troops), research and livestock rearing (together with ruminants) in a sedentary system where they are used for transport activities in the farm $(7,8)$. In the southern part of Nigeria, horses are mainly used for polo games (9). Due to intensive management and extensive uses of these horses and their vivacious temperament, they are often prone to diseases and physical injuries (10, 11) which are often managed with antimicrobials by veterinarians or non-professionals without veterinary supervision. There are no regulations guiding the use of antimicrobials in Nigeria (12). Because horses are prized animals, criticallyimportant antibiotics, including extended-spectrum cephalosporins (ESCs) may be used in treating horses in Nigeria in order to ensure therapeutic success. Thus, these horses may harbour ESC-resistant/ ESBL-producing enterobacteria. These organisms harboured by these horses could be discharged into the environment, thus serving as reservoirs and disseminators of genes encoding $\beta$-lactam resistance and ESBL (13). These genes present in the discharged enterobacteria could be acquired by horizontal transfer to pathogenic human bacteria, thereby complicating infection and compromising antibacterial therapy (13). Direct physical contact between these horses and humans especially their owners, handlers/groomers, jockeys, children and veterinarians, is a putative risk for transmission of ESC-resistant/ESBL-producing enterobacteria $(14,15)$. Indirect contact via contaminated formites (such as grooming gears and saddles), environment and food chain contaminated from environmental discharges, are also a potential risk for transmission of these organisms (16). Evidence supports zoonotic transmission of ESC-resistant/ ESBL-producing enterobacteria from horses (2, 17, 18). Spent (used) horses are transported from the northern region to the southern part of Nigeria where they are slaughtered as source of animal protein. The presence of ESC-resistant/ESBLproducing enterobacteria in the faeces of these horses at slaughter represents a risk for carcass contamination and subsequent contamination of retail meat products, because inadequate hygienic practices are employed during meat processing in Nigeria $(13,19)$. A close association between livestock, horses and humans is inevitable in northern Nigeria (8), which could result in the exchange of ESBL-producing enterobacteria between these hosts. This will consequently result in the fast spread of these organisms in the human and animal population in the country, since majority of the livestock in Nigeria are raised in the northern region. Thus, there is need to screen horses in Nigeria as potential reservoirs of ESBLproducing enterobacteria. Moreover, determination of phenotypic antibacterial resistance/susceptibility profile of ESC-resistant organisms is important for empiric treatment of infections associated with these organisms in horses (20).

The One Health-oriented approach of antimicrobial resistance surveillance involves monitoring of the spread of antibacterial resistance among non-clinical isolates of commensal organisms in hobby and food-producing animals (21). There are a number of reports on isolation of ESC-resistant/ESBL-producing enterobacteria from clinical samples of horses (2, 17, 18, 22-26), but surveillance studies assessing healthy horses as potential reservoirs and disseminators of ESCresistant/ESBL-producing enterobacteria are rather scanty and included reports in the United Kingdom (27, 28) and Czech Republic (17). In Nigeria, investigators have screened animals such as chickens (29-32), ruminants (33-35), pigs $(13,34)$ and dogs $(36)$ as potential reservoirs of ESC-resistant/ESBL-producing enterobacteria. No study has been conducted to screen horses in Nigeria as potential reservoirs of ESC-resistant/ ESBL-producing enterobacteria. The objective of this study, therefore, was to determine the occurrence of ESC-resistant and ESBL-producing enterobacteria in horses at slaughter in the Obollo Afor market, Udenu Local Government Area (L. G. A.), Enugu State Southeast Nigeria and determine the antibacterial resistance/susceptibility profile of the isolates.

\section{MATERIAL AND METHODS}

\section{Study area}

Obollo-Afor is a town in Udenu L. G. A. of Enugu State, Southeastern Nigeria. It is geographically located at coordinates $6.9153^{\circ} \mathrm{N}$ and $7.5139^{\circ} \mathrm{E}$. Obollo-Afor market is a major horse selling and slaughtering point (about 25 horses are killed every 4 days) in Enugu State.

\section{Sampling}

Horses presented for slaughter at the ObolloAfor market/slaughter slab between February 
and June, 2017 were sampled. These ready-toslaughter horses were apparently-healthy and they have been used for various purposes in the northern part of Nigeria and transported to the study site for slaughter and consumption. One hundred and fifty-five horses, consisting 30\% of total slaughter within the period of the study, were selected using a 1:5 systematic random sampling technique. Prior to slaughter, non-duplicate rectal swabs were collected from each of the horse using a sterile swab stick. The samples were transported aseptically in ice packs and processed within 1 hour of collection in the Veterinary Microbiology Laboratory, Department of Veterinary Pathology and Microbiology, University of Nigeria, Nsukka.

Isolation and generic identification of ESCresistant enterobacteria from horses

The swabs were cultured on Mac Conkey agar amended with $4 \mu \mathrm{g} / \mathrm{mL}$ of ceftazidime and incubated at $37^{\circ} \mathrm{C}$ for 24 hours. The morphology of different colonial types were described and recorded appropriately. Purification of the isolates was done by sub-culturing on plain Mac Conkey agar and incubated at $37^{\circ} \mathrm{C}$ for 24 hours. Pure cultures of the isolates were then inoculated onto nutrient agar slants, incubated at $37^{\circ} \mathrm{C}$ for 24 hours and stored in refrigerator at $4{ }^{\circ} \mathrm{C}$ as stock cultures until needed for further analysis. Phenotypic characterization of the isolates to generic level was done by subjecting them to various tests such as Gram staining, oxidase, catalase, urease, methyl red, citrate and triple sugar iron agar test, and subculturing on eosin methylene blue agar following standard methods per Cheesbrough (37).

Determination of antibiogram of generic ESCresistant enterobacterial isolates from horses

Antibacterial resistance/susceptibility profiles of the generic ESC-resistant and ESBL-producing enterobacterial isolates were determined by the disc diffusion method (38), using 17 antibacterial agents in 7 classes: fluoroquinolones - ciprofloxacin (CIP) $(5 \mu \mathrm{g})$, perfloxacin (PEF) $(5 \mu \mathrm{g})$, of loxacin (OFL) $(5 \mu \mathrm{g})$, sparfloxacin (SPA) $(5 \mu \mathrm{g})$, norfloxacin (NOR) $(10 \mu \mathrm{g})$ and enrofloxacin (ENR) $(5 \mu \mathrm{g})$, folate pathway inhibitors - sulphamethoxazoletrimethorpim (SXT-TRI) $(25 \mu \mathrm{g}), \quad \beta$-lactams/ cephalosporins - ampicillin (AMP) $(10 \mu \mathrm{g})$, aztreonam (AZT) $(30 \mu \mathrm{g})$, ceftazidime (CTZ) $(30 \mu \mathrm{g})$, cefotaxime (CTX) $(30 \mu \mathrm{g})$, meropenem (MPN) $(10 \mu \mathrm{g}), \beta$-lactam- $\beta$-lactamase inhibitors - amoxicillin-clavulanic acid (AMC) $(20 / 10 \mu \mathrm{g})$, tetracycline (TET) $(30 \mu \mathrm{g})$, aminoglycosides gentamicin (GEN) $(10 \mu \mathrm{g})$ and streptomycin (STR) $(10 \mu \mathrm{g})$, and phenicol - chloramphenicol (CHL) $(30 \mu \mathrm{g})$. Results of the antibacterial resistance/ susceptibility testing were interpreted according to the Clinical and Laboratory Standards Institute (CLSI) (39) guidelines for aerobic pathogens. Intermediately-susceptible isolates were classified as resistant in this study.

Detection of extended-spectrum $\beta$-lactamase production by generic ESC-resistant enterobacteria from horses

The isolates were screened for ESBL production using the combination disc method (cefpodoxime/ clavulanic acid $[10: 1 \mu \mathrm{g}]$ and cefpodoxime alone $[10 \mu \mathrm{g}]$ on Mueller-Hinton agar. Each test isolate that produced an inhibition zone with a diameter difference of $5 \mathrm{~mm}$ or more between the combination disc and cefpodoxime alone was considered as an ESBL-producer $(38,39)$.

\section{Data analysis}

The frequencies of occurrence of the enterobacterial genera and resistance of the isolates to antibacterial agents were entered into Microsoft Excel version 2010 (Microsoft Corporation, Redmond, USA) and their percentages calculated.

\section{RESULTS}

Occurrence of generic ESC-resistant enterobacteria in horses

Out of 155 rectal swabs cultured, 8 (5.2\%) gave positive culture of ESC-resistant enterobacteria. From these, 11 enterobacterial isolates consisting of 4 (36.4\%) Escherichia coli, 4 (36.4\%) Salmonella spp. and 3 (27.2\%) Proteus spp., were obtained.

Occurrence of generic ESBL-producing enterobacteria in horses

Out of the 11 ESC-resistant isolates, 5 (45.5\%) comprising of all the $4(80 \%)$ E. coli isolates and 1 (20\%) Proteus isolate, were ESBL-producers. Three of the ESBL-producing E. coli were from 3 horses, while 1 ESBL-producing E. coli and the ESBL-producing Proteus isolates were obtained from 1 horse, thus 4 (2.6\%) out of the 155 sampled horses harboured ESBL-producing enterobacteria. 
Antibiogram of generic ESC-resistant and ESBLproducing enterobacterial isolates from horses

Out of the 4 ESBL-producing E. coli isolates, all were resistant to CTZ, CTX, AMP, STR, TET, CHL, SPA, CIP, NOR and ENR, 3 (75\%) to AMC, GEN, PEF and SXT-TRI, 2 (50\%) to OFL and 1
(25\%) to AZT (Fig. 1). All the E. coli isolates were susceptible to MPN.

Out of the 4 ESC-resistant Salmonella isolates, all were resistant to CTZ, CTX, AMP, AZT, AMC, GEN, STR, CHL, TET, SPA, CIP, OFL, NOR and ENR and 2 (50\%) to PEF (Fig. 2). All the Salmonella isolates were susceptible to MPN and SXT-TRI.

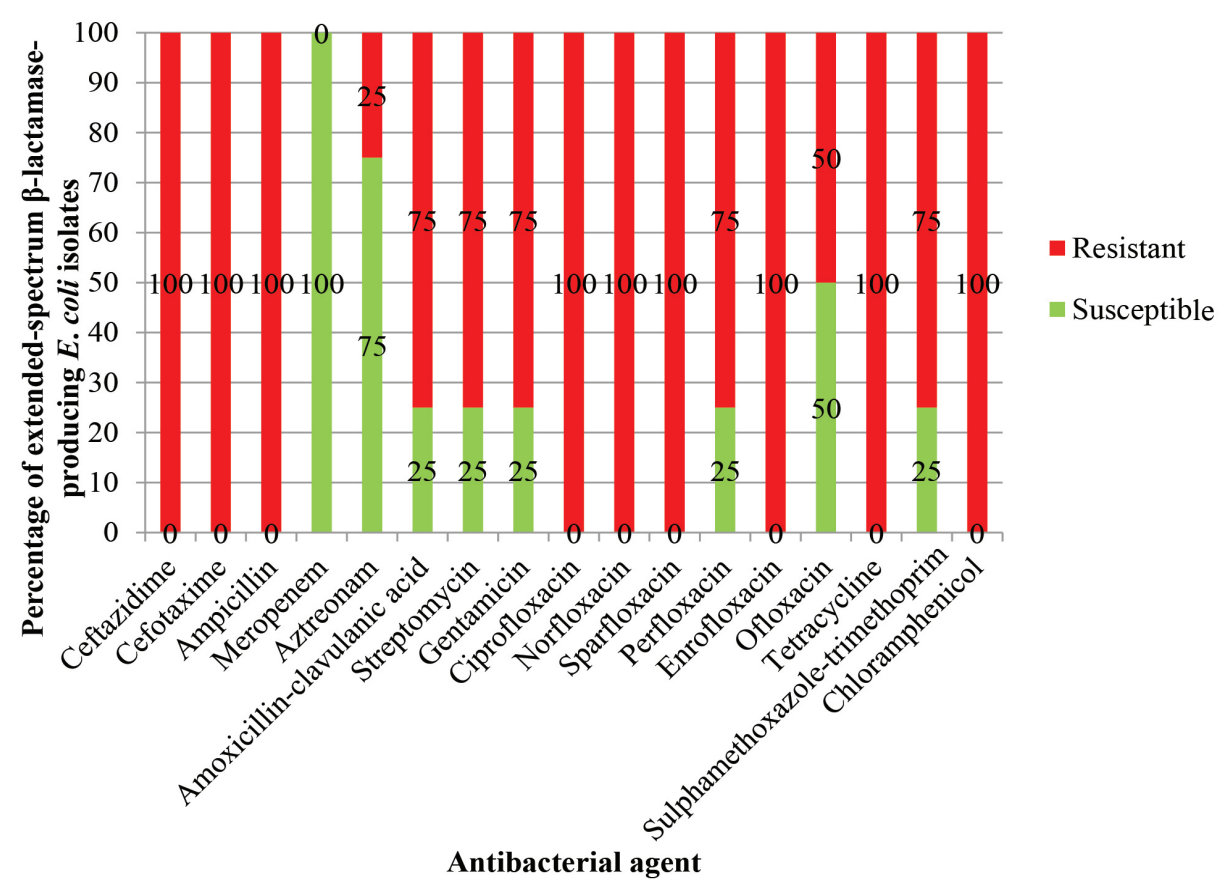

Figure 1. Antibiogram of 4 generic extended-spectrum $\beta$-lactamase-producing Escherichia coli isolates from horses

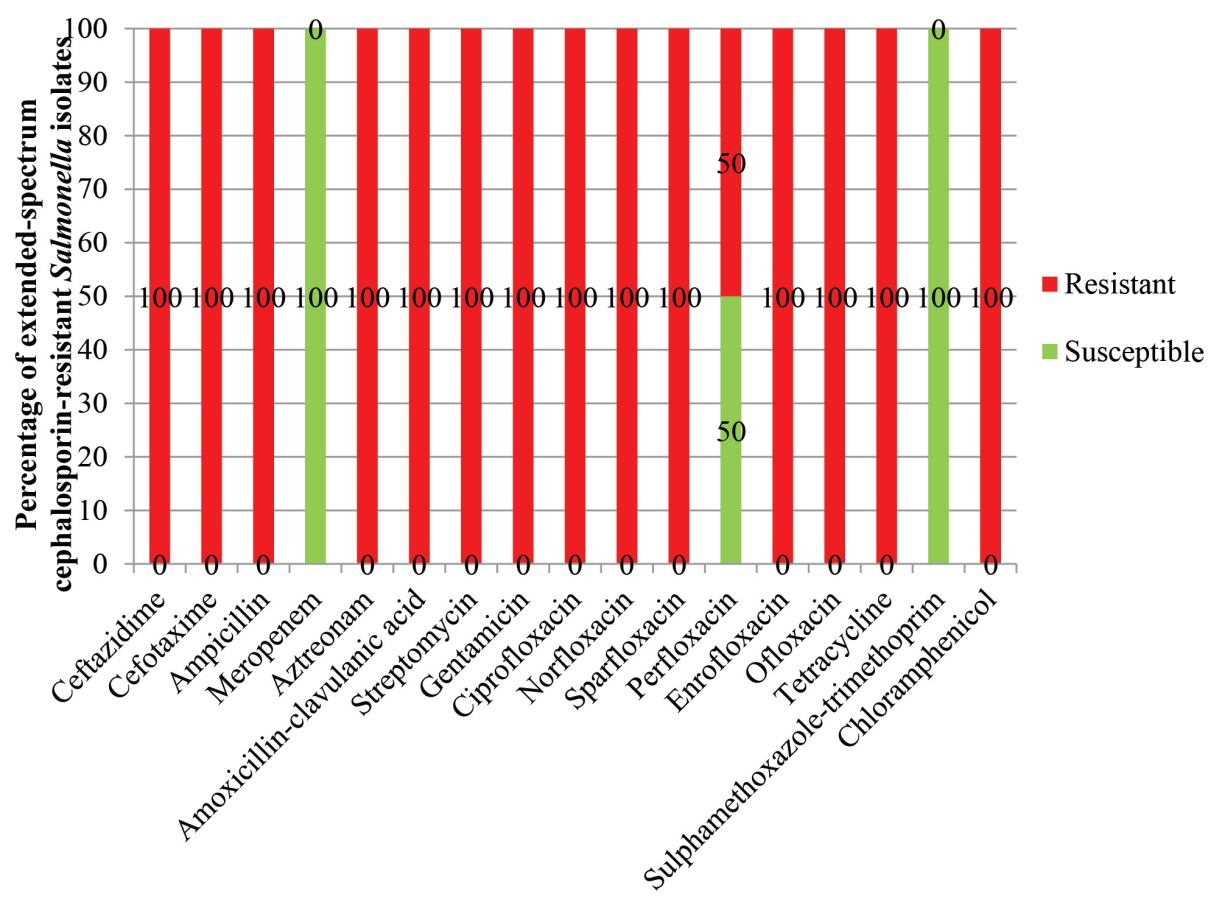

Antibacterial agent

Figure 2. Antibiogram of 4 generic extended-spectrum cephalosporin-resistant Salmonella isolates from horses 


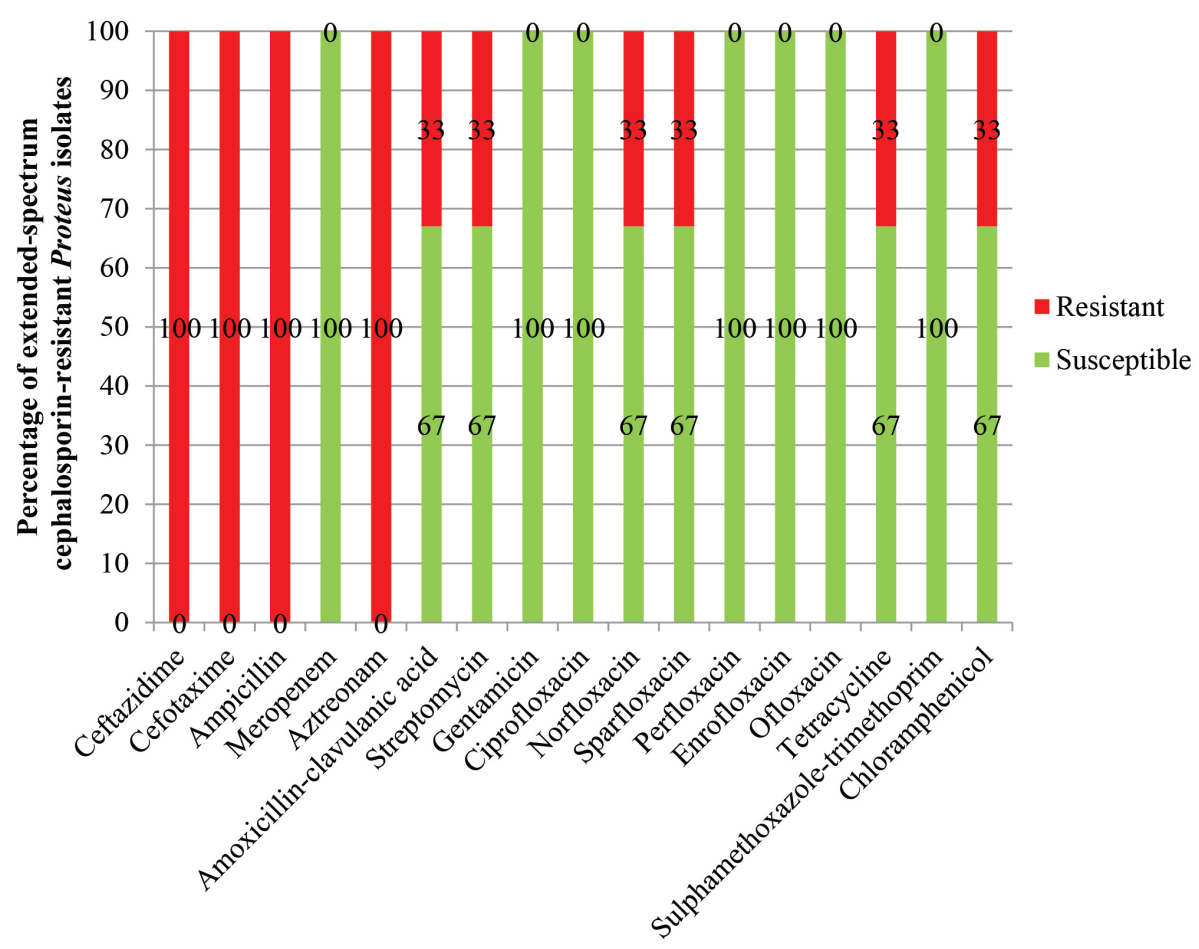

Antibacterial agent

Figure 3. Antibiogram of 3 generic extended-spectrum cephalosporin-resistant Proteus isolates from horses

Out of the 3 ESC-resistant Proteus isolates, all were resistant to CTZ, CTX, AZT and AMP, 33\% to AMC, CHL, STR, TET, SPA and NOR (Fig. 3). All the Proteus isolates were susceptible to MPN, SXT-TRI, GEN, PEF, CIP, OFL and ENR.

All the E. coli and Salmonella isolates were resistant to 3 or more classes of antibacterial agents tested. Two ESC-resistant Proteus isolates were resistant to 2 classes of antibacterial agents tested, while the ESBL-producing isolate exhibited resistance to 3 or more classes of antibacterial agents tested.

\section{DISCUSSION}

The fact that 8 (5.2\%) of the 155 non-duplicate rectal swab samples cultured using Mac Conkey agar supplemented with $4 \mu \mathrm{g} / \mathrm{mL}$ of ceftazidime (an oxyimino-cephalosporin) gave positive growth, suggested that a sizeable percentage of horses in the study area are colonized by ESC-resistant enterobacteria. Isolation of 11 ESC-resistant enterobacteria in 3 genera (4 E. coli, 4 Salmonella and 3 Proteus isolates) from the 8 horses among 155 apparently-healthy horses in this study, suggested that the isolates produced ESBL and/or AmpC $\beta$-lactamases $(15,23)$. This finding calls for concern because these horses potentially serve as reservoirs and disseminators (by faecal shedding) of these organisms into the environment, thereby posing a health threat to individuals that get in contact with them $(2,20,22)$. Veterinarians, jockeys, caretakers and owners of these horses could acquire these organisms following contact with faeces from the horses or contact with formites contaminated by the organisms $(2,14,15,40)$. Since the horses are meant for slaughter, these organisms could also be acquired by the butchers, slaughterhouse workers and consumers following contact with and/or consumption of meat and associated products from the horses $(14,20)$. These individuals could serve as source of dissemination of these organisms to the public $(14,20)$. Possible sources of these organisms in the sampled horses include nosocomial transmission from previous hospital visits, contaminated environment and formites, as well as contaminated feed and/or drinking water $(2,20$, 41). The use of $\beta$-lactams, especially the extendedspectrum cephalosporins in horses, has also been reported to induce selection for ESC resistance (4, 20). Although the medical history of the sampled horses in this study could not be traced since they were used in the northern region and transported 
to the study site, it is possible that they might have been treated earlier with a $\beta$-lactam antibiotic. It is equally possible that the horses might also have been treated earlier with a $\beta$-lactam antibiotic at the study site.

The $5.2 \%$ ESC-resistant enterobacteria occurrence in this study is similar to $5.7 \%$ ESCresistant $E$. coli occurrence among 296 faecal $E$. coli isolates from randomly selected hospitalized horses and horses in livery premises reported by Ahmed et al. (42) in Northwest England. It is worth to note that in Enugu State southeastern Nigeria, Ugwu et al. (13) reported $24.2 \%$ faecal ESC-resistant enterobacterial occurrence among 190 randomly selected healthy pigs using $2 \mu \mathrm{g} / \mathrm{mL}$ of cefotaximeamended MCA, while Anyanwu et al. (36) used 4 $\mu \mathrm{g} / \mathrm{mL}$ of ceftazidime-amended MCA (similar to the current work) and recorded 27\% faecal ESCresistant enterobacteria occurrence among 100 randomly selected healthy dogs in Nsukka Enugu State Nigeria, respectively. These results are higher than the findings $(5.2 \%)$ of this study. The variation in the results of these studies may be related to the differences in the method of sampling, isolation/ processing, type and concentration of ESC used in supplementing the media for primary isolation, concentration of ESC used in the sensitivity test, method used in determining ESC resistance, and usage of $\beta$-lactams in the various study areas (20, 36). The concentration of ESC used in this study has also been used for isolation of ESC-resistant Enterobacteriaeae elsewhere (43).

The lower ESC-resistant enterobacterial occurrence in this study, suggested a lower ESC selection pressure among enterobacteria colonizing these horses than in those that colonized dogs and pigs in Nigeria $(13,36)$. Low ESC selection pressure in enterobacteria in this study may be as a result of infrequent $\beta$-lactam antibiotic treatment given to these horses raised in the northern region of Nigeria, where they are used for several purposes, and then transported down to the southern region of the country where they are kept for a short time and slaughtered for food $(10,11)$. It is also possible that a higher occurrence rate of ESC-resistant enterobacteria than as observed in this study might have been recorded, if simple random sampling was used rather than systematic random sampling.

In this study, 34.6\% ESC-resistant E. coli and Salmonella occurrence and 27.2\% ESC-resistant Proteus occurrence was observed. Anyanwu et al. (36) reported E. coli as the predominant (40.7\%) ESC-resistant enterobacteria in dogs, whereas Ugwu et al. (13) recorded Klebsiella as the most prevalent
(67.4\%) ESC-resistant enterobacterial isolates from pigs. The differences in the predominance of enterobacteria genera isolated in these studies may be related to the disparity in usage of ESCs in management of the different animal species.

Detection of ESBL-producing enterobacteria in $4(2.6 \%)$ of the 155 sampled horses in this study, further indicated that the horses are potential reservoirs of ESBL-producing enterobacteria, while it also further proves that the isolates produced ESBL. The result also suggested a low occurrence of ESBL-producing enterobacteria in horses in the study area. It may also mean that a low proportion of enterobacteria colonizing horses in the study area have acquired genes encoding ESBL. The 2.6\% ESBL-producing enterobacteria occurrence in this study is lower than 6.3, 84, 32 and 100\% ESBLproducing $E$. coli occurrence in faecal samples of 650 horses in a community in UK (28), faecal/ wound samples of 91 hospitalized and hospital resident horses in the Netherlands (2), faecal samples of 37 horses in equine clinic and horse riding back centers in Czech Republic (17) and faecal samples of 10 horses that received antibacterial treatment in Denmark (44), respectively. Differences in these studies could be attributed to variations in health status of the animals (whether sick or healthy), type of sample analyzed, method of detection of ESBL production (whether phenotypic or molecular), and degree of contamination of horses'/animals' environment and colonization $(2,36,44)$. In the experiment presented hereby, combination disc diffusion method utilizing cefpodoxime (an ESC) with and without clavulanic acid, was employed in detecting ESBL production $(38,39)$. This recommended method has proved to be reliable (but not as molecular methods) in detection of ESBL production in enterobacterial isolates $(38,39)$. Overexpression of non-ESBL (such as TEM-1 and OXA1) and loss of porins could result in false ESBL phenotypes (45). Therefore, it is possible that the occurrence rate of ESBL-producing enterobacteria in horses sampled in this study may not be detected as much by the combination disc test (a phenotypic ESBL production detection method) used in this study.

Detection of 5 (45.5\%) ESBL-producing enterobacteria (4/4 E. coli and 1/3 Proteus isolates) among 11 ESC-resistant enterobacteria in this study, suggested that horses in the study area are colonized by different ESBL-producing enterobacterial genera. It also suggested that either the horses already harboured the ESBL-producing organisms or that the isolates acquired genes encoding ESBL 
from other enterobacteria in the gut (2). The use of antibiotics, including extended-spectrum cephalosporins, in horses and other animals are not regulated in Nigeria $(12,13)$. Thus, the findings also suggested that these horses might have been treated with ESCs during previous visitations to hospital or by their owners or handlers. It is also possible that they have been treated with these drugs or acquired ESBL-producing enterobacteria while awaiting slaughter at the study site. Unfortunately, there is no pre-slaughter assessment to detect the possible use of these drugs in horses in Nigeria. The finding of ESBL-producing enterobacteria in this study is worrisome, because ESBL-producing organisms rapidly transfer MDR genes (by plasmids) to other bacteria by horizontal transfer following acquisition by individuals (such as groomers, veterinarians, jockeys and owners) in direct contact with carrier animals (4). Ingestion of raw horse meat as practiced by some butchers in Nigeria and consumption of undercooked meat, are also putative risk for acquisition of ESBL-producing organisms from these horses; this is because of the high risk of carcass contamination due to poor hygienic practices employed during animal slaughter in Nigeria (13, 19). In Germany, Schmeidel et al. (22) observed $37 \%$ ESBL-producing enterobacteria occurrence among 100 ESC-resistant enterobacterial isolates from different samples of sick horses, a finding that is lesser than the result $(45.5 \%)$ of this study. Vo et al. (27) detected 85.7\% ESBL-production among 7 ESC-resistant enterobacterial isolates from horses in the Netherlands, this result is higher than the finding (45.5\%) of this study.

Phenotypic confirmation of all the ESCresistant $E$. coli isolates in this study as ESBLproducers is similar to the findings of Smet et al. (24) that all 5 cephalosporin-resistant E. coli isolates from diseased horses in Belgium were ESBL-producers. A retrospective study conducted in Switzerland, reported 60\% ESBL-producing $E$. coli occurrence among 60 clinical $E$. coli isolates from different samples of horses (26), while a Dutch study observed 99.5\% ESBL-producing $E$. coli occurrence among 198 faecal/wound E. coli isolates from horses (2); these findings are lesser than the result (100\%) of the current study. Previous studies in Nigeria (which did not use ESC-amended media for primary isolation) reported 16.3-44.7\% and 8.9-22.5\% ESBL-producing E. coli occurrence among $E$. coli isolates from cattle $(34,35)$ and chickens $(29,31,33)$, respectively. These results are also lesser than the findings $(100 \%)$ of this study. Variation in the detection rate of ESBL-producing
E. coli in these studies may be related to differences in use of ESCs in the study areas, contamination of feed, drinking water and/or environment, infection and colonization of the animals by the organisms. Detection of $4(80 \%)$ ESBL-producing E. coli isolates compared against 1 (20\%) Proteus isolate in this study, suggested that E. coli may be the predominant ESBL-producing enterobacterial genus colonizing horses in the study area.

Interestingly, none of the isolates in this study exhibited resistance to MPN (a carbapenem) which is the last resort drug for treating infections associated with extended-spectrum $\beta$-lactamresistant-, ESBL- and AmpC $\beta$-lactamasesproducing, and other MDR bacteria $(12,13)$. This finding suggested that carbapenems have not been abused in equine practice in Nigeria.

\section{CONCLUSION}

This study has shown that ESC-resistant (5.2\%) and ESBL-producing (2.6\%) enterobacteria are harboured by a sizeable percentage of horses slaughtered at the Obollo Afor market in Udenu L. G. A., Southeastern Nigeria. E. coli is the dominant genus of ESBL-producing enterobacteria colonizing horses in the study area. Thus, these horses are potential reservoirs and disseminators of ESCresistant/ESBL-producing enterobacteria and genes encoding ESBL and AmpC $\beta$-lactamases. This has tremendous impact on the food chain, ecology and epidemiology of antibacterial resistance. Therefore, attention should be paid on the use of ESCs in horses in Nigeria. However, further studies to determine the genes encoding ESBL and/or AmpC $\beta$-lactamases in the isolates are recommended.

\section{CONFLICT OF INTEREST STATEMENT}

The authors declared that they have no potential conflict of interest with respect to the authorship and/or publication of this article.

\section{ACKNOWLEDGMENT}

The authors are grateful to Prof. Kennedy F. Chah for providing the combination discs used in this study 


\section{REFERENCES}

1. Huber, H., Zweifel, C., Wittenbrink, M.M., Roger, S. (2013). ESBL-producing uropathogenic Escherichia coli isolated from dogs and cats in Switzerland. Vet Microbiol. 162, 992-996.

https://doi.org/10.1016/j.vetmic.2012.10.029 PMid:23177909

2. Apostolakos, I., Franz, E., van Hoek, A.H.A.M., Florijn, A., Veenman, C., Sloet-van OldruitenborghOosterbaan, M.M., Dierikx, C., van Duijkeren, E. (2017). Occurrence and molecular characteristics of ESBL/AmpC-producing Escherichia coli in faecal samples from horses in an equine clinic. $\mathrm{J}$ Antimicrob Chemother. 72 (7): 1915-1921. https://doi.org/10.1093/jac/dkx072 PMid:28333298

3. World Health Organization (WHO) (2017). Global priority list of antibiotic-resistant bacteria to guide research, discovery, and development of new antibiotics http://www.who.int/medicines/ publications/WHO-PPL-Short_Summary_25FebET_NM_WHO.pdf

4. Dierikx, C.M., van Duijkeren, E., Schoormans, A.H., van Essen-Zandbergen, A., Veldman, K., Kant A., Huijsdens XW., van der Zwaluw K., Wagenaar JA., Mevius DJ. (2012). Occurrence and characteristics of extended-spectrum- $\beta$-lactamase- and AmpCproducing clinical isolates derived from companion animals and horses. J Antimicrob Chemother. 67(6): 1368-1374.

https://doi.org/10.1093/jac/dks049

PMid:22382469

5. Olusa, T.A.O., Adegunwa, A.K., Aderonmu, A.A., Adeyefa, C.A.O. (2010). Serologic evidence of equine $\mathrm{H} 7$ influenza virus in polo horses in Nigeria. Sci World J. 5(2):17-19.

https://doi.org/10.4314/swj.v5i2.61509

6. Turaki, U.A., Kumsha, H.A., Biu, A.A., Bokko, P.B. (2014). Prevalence of piroplasmosis amongst local horses in Northeastern Nigeria. IOSR J Agric Vet Sci. 7(12): 4-7.

7. Ehizibolo, D.O., Kamani, J., Eizibolo, P.O., Egwu, K.O., Dogo, G.I., Salami-Shinaba, J.O. (2012). Prevalence and significance of parasites of horses in some states of Northern Nigeria. J Equine Sci. 23(1): 1-4.

https://doi.org/10.1294/jes.23.1

PMid:24833991 PMCid:PMC4013976

8. Ardo, B., Abubakar, D.M. (2016). Seroprevalence of horse (Equus caballus) brucellosis on the Mambilla plateau of Taraba State, Nigeria. J Equine Sci. 27(1): 1-6.

https://doi.org/10.1294/jes.27.1

PMid:27073329 PMCid:PMC4828245
9. Sule, WF, Oluwayelu, D.O., Adedokun, R.A.M., Rufai, N., McCracken, F., Mansfield, K.L., Johnson, N. (2015). High seroprevelance of West Nile Virus antibodies observed in horses from Southwestern Nigeria. Vec Borne Zoonot Dis. 15(3): 218-220.

https://doi.org/10.1089/vbz.2014.1706

PMid:25793479 PMCid:PMC4369928

10. Agina, O.A., Ihedioha, J.I., Anyanwu, M.U., Ngwu, M.I. (2016). Clinicopathological and microbiological findings associated with wounds in Nigerian horses. Comp Clin Pathol. 26 (1): 181-188.

11. Agina, O.A., Ihedioha, J.I. (2017). Occurrence of wounds in Nigerian horses. J Appl Anim Welf. Sci. https://doi.org/10.1080/10888705.2017.1343149 PMid:28696771

12. Alonso, C.A., Zarazaga, M., Ben Sallem, R., Jouini, A., Ben Slama, K., Torres, C. (2017). Antibiotic resistance in Escherichia coli in animal husbandry: the African perspective. Lett Appl Microbiol. 64, 318-334.

https://doi.org/10.1111/lam.12724

PMid:28208218

13. Ugwu, I.C., Anyanwu, M.U., Ugwu, C.C., Ugwuanyi, O.W. (2015). Prevalence and antibiogram of generic extended-spectrum $\beta$-lactam-resistant enterobacteria in healthy pigs. Not Sci Biol. 7(3): 273-280.

https://doi.org/10.15835/nsb.7.3.9616

14. Huijbers, P.M., de Kraker, M., Graat, E.A., van Hoek, A.H., van Santen, M.G., de Jong, M.C., van Duijkeren, E., de Greeff, S.C. (2013). Prevalence of extended-spectrum $\beta$-lactamaseproducing Enterobacteriaceae in humans living in municipalities with high and low broiler density. Clin Microbiol Infect. 19(6): E256-59. https://doi.org/10.1111/1469-0691.12150 PMid:23397953

15. Maddox, T.W., Clegg, P.D., Williams, N.J., Pinchbeck, G.L. (2015). Antimicrobial resistance in bacteria from horses: Epidemiology of antimicrobial resistance. Equine Vet J. 47(6): 756-765.

https://doi.org/10.1111/evj.12471

PMid:26084443

16. Woerther, P., Burdet, C., Chachaty, E., Andremont, A. (2013). Trends in human fecal carriage of extendedspectrum- $\beta$-lactamases in the community: toward the globalization of CTX-M. Clin Microbiol Rev. 26(4): 744-758.

https://doi.org/10.1128/CMR.00023-13

PMid:24092853 PMCid:PMC3811232 
17. Dolejska, M., Duskova, E., Rybarikova, J., Janoszowska, D., Roubalova, E., Dibdakova, K., Maceckova, G., Kohoutova, L., Literak, I., Smola, J., Cizek, A. (2011). Plasmids carrying blaCTX-M-1 and qnr genes in Escherichia coli isolates from an equine clinic and a horseback riding centre. $\mathrm{J}$ Antimicrob Chemother 66(4): 757-764. https://doi.org/10.1093/jac/dkq500 PMid:21393204

18. Ewers, C., Stamm, I., Pfeifer, Y., Wieler, L.H., Kopp, P.A., et al. (2014). Clonal spread of highly successful ST15-CTX-M-15 Klebsiella pneumoniae in companion animals and horses. J Antimicrob Chemother 69(10): 2676-2680.

https://doi.org/10.1093/jac/dku217

PMid:24974381

19. Faleke, O.O., Jolayemi, K.O., Igoh, Y.O., Jibril, A.H., Ayedun, J.O. (2017). Salmonella species on meat contact surfaces and processing water in Sokoto main market and abattoir, Nigeria. Mac Vet Rev. 40(1): 59-65.

https://doi.org/10.1515/macvetrev-2017-0011

20. Johns, I.C., Adams, E.L. (2015). Trends in antimicrobial resistance in equine bacterial isolates: 1999-2012. Vet Rec.

https://doi.org/10.1136/vr.102708

PMid:25628448

21. World Health Organization (WHO) (2014). Antimicrobial resistance: global report on surveillance. World Health Organization

22. Schmiedel, J., Falgenhauer, L., Domann, E., Bauerfeind, R., Prenger-Berninghoff, E., et al. (2014). Multiresistant extended-spectrum $\beta$-lactamase-producing Enterobacteriaceae from humans, companion animals and horses in central Hesse, Germany. BMC Microbiol. 14, 187. https://doi.org/10.1186/1471-2180-14-187 PMid:25014994 PMCid:PMC4105247

23. Vo, A.T., van Duijkeren, E., Fluit, A.C., Gaastra, W. (2007). Characteristics of extended-spectrum cephalosporin-resistant Escherichia coli and Klebsiella pneumoniae isolates from horses. Veterinary Microbiol. 124(3-4): 248-255. https://doi.org/10.1016/j.vetmic.2007.04.027 PMid:17521833

24. Smet, A., Boyen, F., Flahou, B., Doublet, B., Praud, K., Martens, A., Butaye, P., Cloeckaert, A., Haesebrouck, F. (2012). Emergence of CTX-M2-producing Escherichia coli in diseased horses: evidence of genetic exchanges of bla (CTX-M-2) linked to ISCR1. J Antimicrob Chemother. 67(5): 1289-1291.

https://doi.org/10.1093/jac/dks016

PMid:22328640
25. Ewers, C., Bethe, A., Stamm, I., Grobbel, M., Kopp, PA, et al. (2014). CTX-M-15-D-ST648 Escherichia coli from companion animals and horses: another pandemic clone combining multiresistance and extraintestinal virulence? J Antimicrob Chemother. 69(5): 1224-1230.

https://doi.org/10.1093/jac/dkt516

PMid:24398338

26. van Spijk, J.N, Schmitt, S., Fürst, A.E., Schoster, A. (2016). A retrospective analysis of antimicrobial resistance in bacterial pathogens in an equine hospital (2012-2015). Schweiz Arch Tierheilkd. 158(6): 433-442.

https://doi.org/10.17236/sat00069

PMid:27504838

27. Maddox, T.W., Clegg, P.D., Diggle, P.J., Wedley, A.L., Dawson, S., Pinchbeck, G.L., Williams, N.J. (2012). Cross-sectional study of antimicrobialresistant bacteria in horses. Part 1: Prevalence of antimicrobial-resistant Escherichia coli and methicillin-resistant Staphylococcus aureus. Equine Vet J. 44(3): 289-296. https://doi.org/10.1111/j.2042-3306.2011.00441.x PMid:21848534

28. Maddox, T.W., Pinchbeck, G.L., Clegg, P.D., Wedley, A.L., Dawson, S., Williams, N.J. (2012). Cross-sectional study of antimicrobial-resistant bacteria in horses. Part 2: Risk factors for faecal carriage of antimicrobial-resistant Escherichia coli in horses. Equine Vet J. 44(3): 297-303.

https://doi.org/10.1111/j.2042-3306.2011.00440.x PMid:21848536

29. Chah, K.F., Oboegbulem, S.I. (2007). Extended spectrum beta-lactamase production among ampicillin-resistant Escherichia coli strains from chicken in Enugu State, Nigeria. Braz J Microbiol. 38, 681-686. https://doi.org/10.1590/S1517-83822007000400018

30. Duru, C., Nwanegbo, E., Adikwu, M., Ejikeugwu, C., Esimone, C. (2013). Extended-spectrum betalactamase-producing Escherichia coli strains of poultry origin in Owerri, Nigeria. World J Med Sci. 8(4): 349-354.

31. Eze, E., Nwakeze, E., Oji, A., Ejikeugwu, C., Iroha, I. (2013). Microbiological investigation of Escherichia coli isolates from cloacal and feacal swabs of broiler chickens for extended- spectrum beta-lactamase (ESBL) enzymes. J Pharm Biol Sci. 7(5): 96-99.

32. Ojo, O.E., Schwarz, S., Michael, G.B. (2016). Detection and characterization of extendedspectrum $\beta$-lactamase-producing Escherichia coli from chicken production chains in Nigeria. Vet Microbiol. 194, 62-68. https://doi.org/10.1016/j.vetmic.2016.04.022 PMid:27157499 
33. Abubakar, M.B., Salihu, M.D., Aliyu, R.M., Bello, A., Tukur, H., Shuaibu, A.B. (2016). Occurrence and antimicrobial resistance of ESBL-producing Escherichia coli in indigenous chickens and retailed table-eggs in Sokoto metropolis, Nigeria. Schol J Biol Sci. 5(2): 56-60

34. Olowe, O.A., Adewumi, O., Odewale, G., Ojurongbe, O., Adefioye, O.J. (2015). Phenotypic and molecular characterization of extended-spectrum betalactamase producing Escherichia coli obtained from animal fecal samples in Ado Ekiti, Nigeria. J Env Publ Health

35. Ogefere, H.O., Agbe, S.O., Ibadin, E.E. (2017). Detection of extended-spectrum beta-lactamases among Gramnegative bacilli recovered from cattle faeces in Benin city, Nigeria. Not Sci Biol. 9(2):177-181.

https://doi.org/10.15835/nsb9210005

36. Anyanwu, M.U., Ugwu, I.C., Ezekwelu, M.O., Okoroafor, U.N. (2017). Prevalence and antibiogram of generic extended $\beta$-lactam-resistant enterobacteria in healthy dogs. Not Sci Biol. 9(1): 22-33.

https://doi.org/10.15835/nsb919940

37. Cheesebrough, M. (2000). District laboratory practice in tropical countries Part 2. Cambridge University Press; Cambridge, pp. 63-70.

38. Clinical and Laboratory Standards Institute (CLSI) (2014). Performance standards for antimicrobial susceptibility testing; twenty-fourth informational supplement, M100-S24 34(1): 61-188.

39. Clinical and Laboratory Standards Institute (CLSI) (2017). Performance standards for antimicrobial susceptibility testing, 27th Edition M100.

40. Walther, B., Lübke-Becker, A., Stamm, I., Gehlen, H., Barton, A.K., Janssen, T., Wieler, L.H., Guenther, S. (2014). Suspected nosocomial infections with multidrug resistant E. coli, including extended-spectrum beta-lactamase (ESBL)-producing strains, in an equine clinic. Berl Munch Tierarztl Wochenschr. 127(11-12): 421-427.

PMid:25872251
41. Hagget, E.F. (2014). Antimicrobial use in foal: do we need to change how we think? Equine Vet J. 46, 137-138. https://doi.org/10.1111/evj.12178

PMid:24548374

42. Ahmed, M.O., Clegg, P.D., Williams, N.J., Baptiste, K.E., Bennett, M. (2010). Antimicrobial resistance in equine faecal Escherichia coli isolates from North West England. Ann Clin Microbiol Antimicrob. 9, 12. https://doi.org/10.1186/1476-0711-9-12 PMid:20374640 PMCid:PMC2867969

43. Schaufler, K., Bethe, A., Lubke-Becker, A., Ewers, C., Kohn, B., Wieler, L.H., Guenther, S. (2015). Putative connection between zoonotic multiresistant extended-spectrum beta-lactamase (ESBL)-producing Escherichia coli in dog feces from a veterinary campus and clinical isolates from dogs. Infect Ecol Epidemiol. 5, 25334.

https://doi.org/10.3402/iee.v5.25334 PMid:25656467 PMCid:PMC4318939

44. Damborg, P., Marskar, P., Baptiste, K.E., Guardabassi, L. (2012). Faecal shedding of CTXM-producing Escherichia coli in horses receiving broad-spectrum antimicrobial prophylaxis after hospital admission. Vet Microbiol. 154(3-4): 298304.

https://doi.org/10.1016/j.vetmic.2011.07.005 PMid:21820821

45. Beceiro, A., Maharjan, S., Gaulton, T., Doumith, M., Soares, N.C., Dhanji, H., et al. (2011). False extended-spectrum \{beta\}-lactamase phenotype in clinical isolates of Escherichia coli associated with increased expression of OXA-1 or TEM-1 penicillinases and loss of porins. J Antimicrob Chemother. 66, 2006-2010. https://doi.org/10.1093/jac/dkr265 PMid:21742679

Please cite this article as: Anyanwu M.U., Ugwu I.C., Onah C.U. Occurrence and antibiogram of generic extended-spectrum cephalosporin-resistant and extended-spectrum $\beta$-lactamase-producing enterobacteria in horses. Mac Vet Rev 2018 ; 41 (2): $123-132$. https://doi.org/10.2478/macvetrev-2018-0015 